\title{
地域医療の中で薬剤師に期待すること一がん診療の立場から一
}

\author{
高木正和
}

\section{Pharmasists in the Community Medicine: Especially in Cancer Treatment}

\author{
Masakazu TAKAGI \\ Department of Surgery, Shizuoka General Hospital, 4-27-1 Kitaandou, Aoi-ku, Shizuoka 420-8527, Japan
}

(Received September 1, 2010)

\begin{abstract}
It is important for clinics and hospitals to cooperate in treating cancer patients in the community health. We are treating cancer patients in cooperation with five general hospitals in Shizuoka and about 100 clinics in the same community. In this system, it is required that pharmacists in the community should have knowledge about beneficial effects and adverse events of anticancer drugs as do hospital pharmacists, and furthermore they should have good communication with cancer patients. The expectation for pharmacists is great in community medicine especially in the treatment of cancer patients.
\end{abstract}

Key words_clinical pathway; community health; cancer treatment

\section{1. はじめに}

がんに対する医療構造は平成 18 年 6 月の “がん 対策基本法”1)の成立以来急速に整備が進んでいる. この中でがん診療連携拠点病院を中心に，がん診療 の質の均てん化を図り，がん診療が地域で完結する ことが強く求められている. ${ }^{2,3)}$

このような状況の中，われわれは静岡市がん診療 地域連携協議会を組織し, 平成 19 年 5 月より静岡 市内 5 力所のすべての総合病院と静岡市医師会との 間でがん診療に関する地域連携クリティカルパスを 作成し，運用してきた。

この地域連携クリティカルパスを紹介し，これを 通して地域医療におけるがん診療の中でわれわれが 薬剤師に期待することを述べたい.

2. 地域連携クリティカルパス ${ }^{4,5)}$ とは

クリティカルパスとは良質な医療を効果的，かつ 安全, 適正に提供するための手段として開発された 診療計画表である。もとは 1950 年代に米国の工業 界で導入され始め, 1990 年代にわが国の医療機関 で導入が始まった。このクリティカルパスを導入す

静岡県立総合病院消化器センター外科（†420-8527 静 岡市葵区北安東 4-27-1)

e-mail: masa-takagi@general-hosp.pref.shizuoka.jp 本総説は, 日本薬学会第 130 年会シンポジウム S03 で 発表したものを中心に記述したものである.
ることにより，診療の標準化，根拠に基づく医療の 実践，インフォームドコンセントの充実，業務の改 善, チーム医療の向上などが期待されている.

地域連携クリティカルパスとは急性期病院から回 復期病院を経て早期に自宅に帰れるような診療計画 書を作成し，治療を受けるすべての医療機関で共有 して用いるものである。診療にあたる複数の医療機 関が，役割分担を含め，あらかじめ診療内容を患者 に提示・説明することにより，患者が安心して医療 を受けることができる，内容としては，施設毎の治 療経過に従って, 診療ガイドライン等に基づき, 診 療内容や達成目標等を診療計画として明示する。こ れにより，医療連携体制に基づく地域完結型医療を 具体的に実現することができる.

\section{3. 静岡市がん診療地域連携協議会（s-net）}

病院と診療所が共通した考えの下，お互いの役割 を明確にすることにより，患者が安心かつ満足でき る診療体制を構築し，さらに状況に応じ訪問看護又 テーション・地域の薬局・介護施設と協力し，切れ 目のない連携体制を構築することを目的として組織 された．参加団体は，静岡県立総合病院，市立静岡 病院, 静岡赤十字病院, 静岡済生会病院, 静岡厚生 病院の 5 つの総合病院と静岡市医師会に所属する診 療所, 静岡市薬剂師会, 静岡ケアマネ協会, 静岡訪 問看護ステーション連絡会である. 
この s-net では胃がん，大腸がん，乳がん，肺が んにつき静岡市内 5 つの総合病院と静岡市医師会が 共通の術後診療用パスを用いて病診連携を実践して いる. 術後補助化学療法についても疾患毎の共通パ スを運用し, 病診連携で治療を行うとともに, 病 院・診療所・薬局・訪問看護ステーション・ケアマ ネージャーによる在宅緩和ケアチームの構築も行っ ている (Fig. 1).

3-1. s-net がん術後経過観察パス s-net では 静岡市内 5 病院と静岡市医師会の診療所との間で, 胃がん, 大腸がん, 乳がん, 肺がんにつきそれぞれ の進行度に応じた共通の術後経過観察パスを構築し 運用している. まず手術後病院からの患者情報は病 診連携担当者を通じて医師会（s-net 本部）に登録 されるとともに診療所に伝えられる（Fig. 2)，定 められた間隔で定期検査を行う病院と診療所は病診 連携担当者を通して患者情報を受け渡しする（Fig. 3). 術後経過観察の軸足は地域の診療所に置くこと を共通認識とし，診療所と病院がそれぞれ術後のど の時期にどのような検査を実施するかを規定し, 検 查の重複や患者の経過観察からの逸脱を防いでい る. 例えば胃の進行がん（Fig. 4) では診療所の受 診は 3 カ月毎でその都度腫瘍マーカーを含む血液検 查を行い, 6 力月毎に腹部超音波検査と胃内視鏡検 查を行う。一方病院の受診は 6 力月毎で毎回診察と 腹部 CT を施行する。このように各がん腫により考 えられる再発の早期発見と術後全身状態のチェック
を診療所と病院とで過不足なく実施している．シス テムの稼働以来 3 年を経過したが，これまで 660 名 以上の症例でこのパスが運用されている.

3-2. s-netによるがん術後補助化学療法パス s-net では静岡市内 5 病院と静岡市医師会の診療 所との間で, 胃がん, 大腸がん, 乳がん, 肺がんに つき共通の術後補助化学療法のパスを構築し運用し ている，胃がん，大腸がん，肺がんについてはフッ 化ピリミジン系経口抗がん剂を，乳がんについては 分子標的治療薬のトラスツマブを使用する.

化学療法あるいは分子標的治療薬使用の際に重要 な点は, 治療前の十分な服薬指導と有害事象の早期 発見である，パスでは代表的な有害事象を明記し， その重症度表記をわかり易く示したうえで次コース

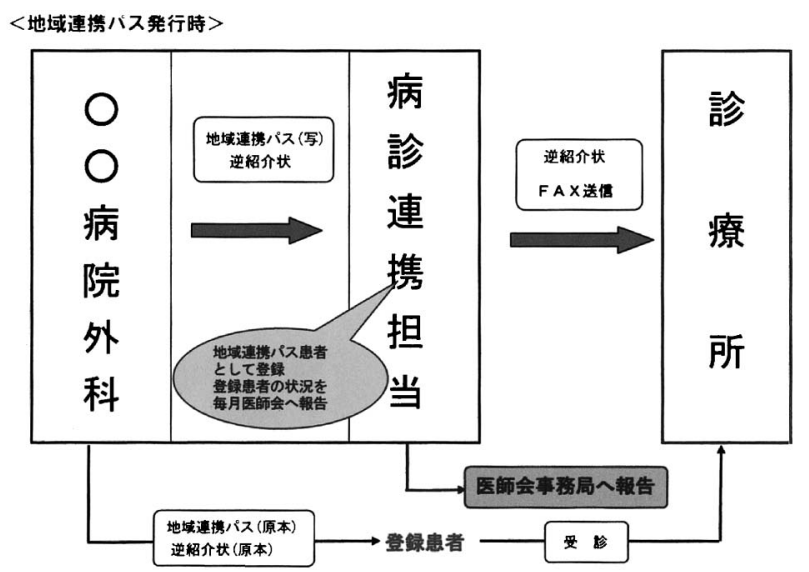

Fig. 2. Flow of the Patients in "s-net"-1

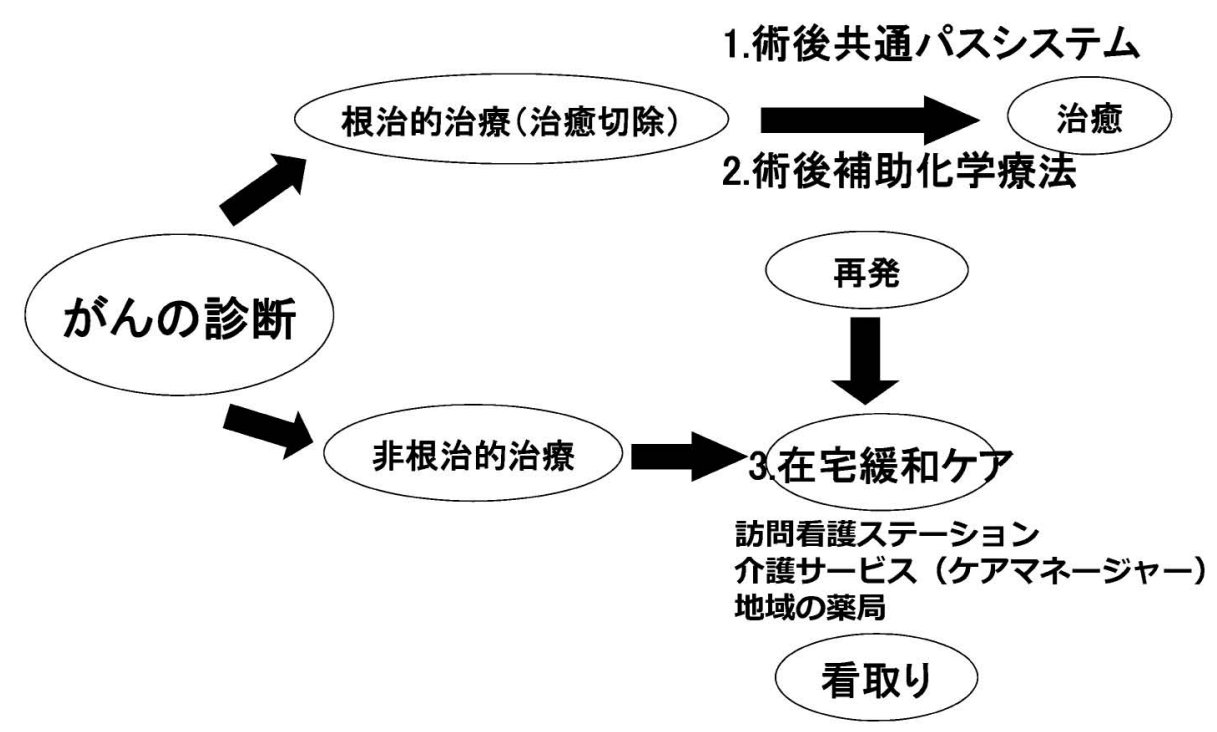

Fig. 1. Local Communication System between Hospitals and Clinics 


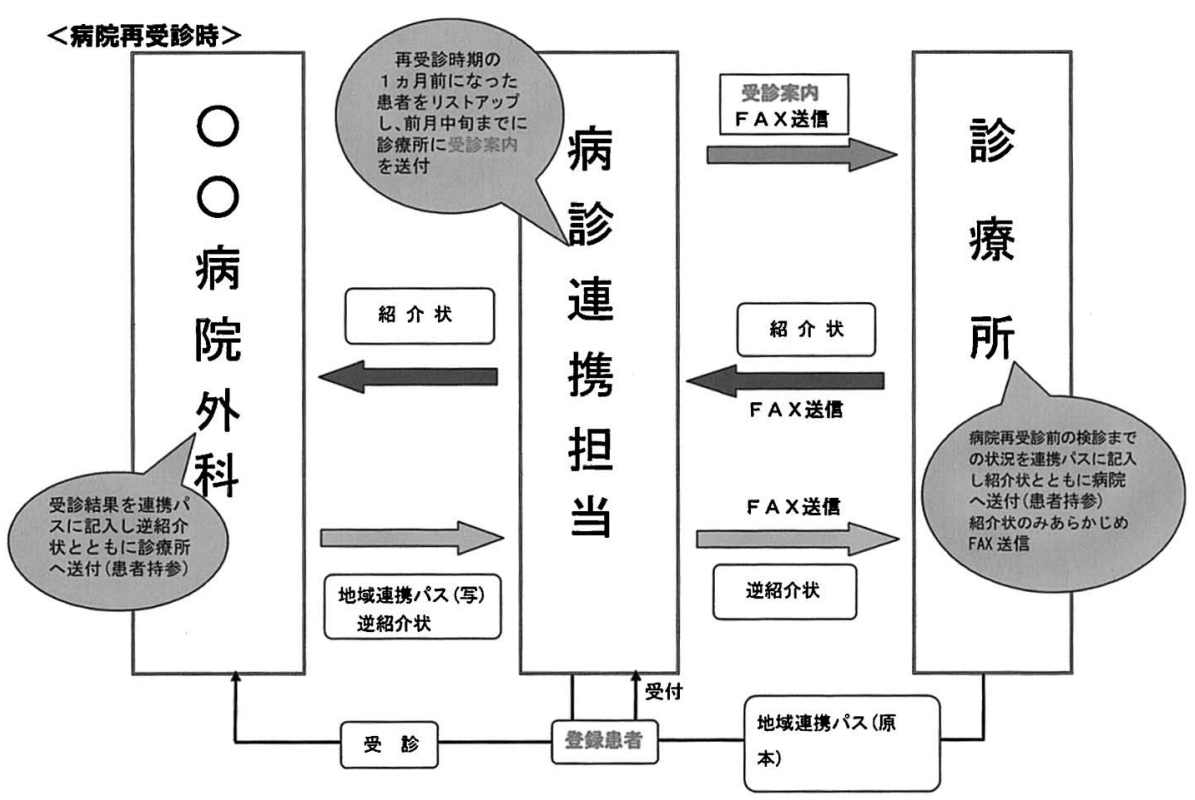

Fig. 3. Flow of the Patients in "s-net"-2

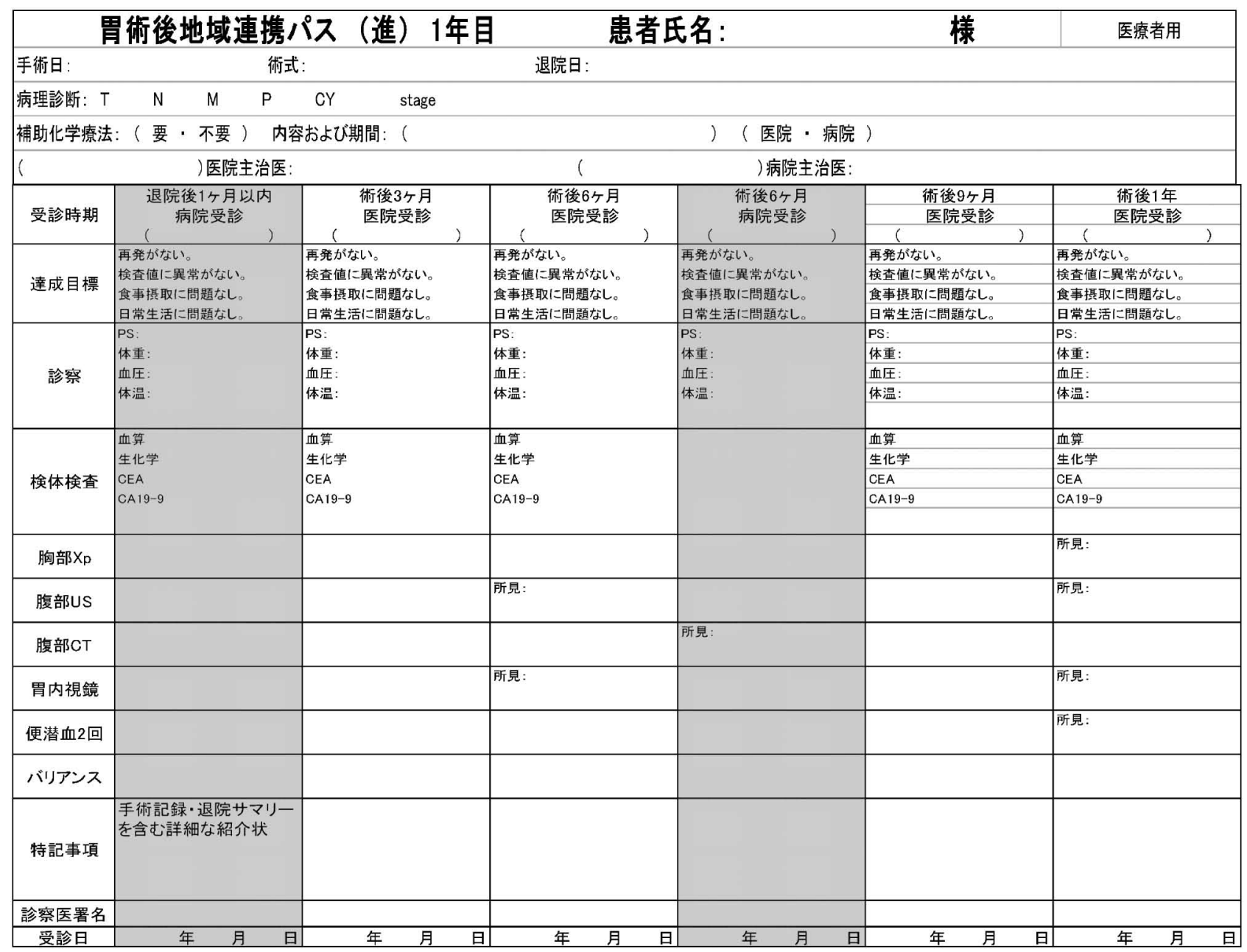

Fig. 4. Postoperative Clinical Pathway for the Patient of Advanced Gastric Cancer 
開始時の減量規定なども示している. 現在術後補助 療法の最初の数回を病院で実施し, 重篤な有害事象 が起こらないことを確認後パスを適用して診療所と の連携を開始している.

3-3. s-net による在宅緩和医療6） s-net では静 岡市内 5 病院と静岡市医師会の診療所との間で共通 の “在宅緩和医療シート”を作成している。各病院 の緩和チーム担当者はこのシートの中の “在宅緩和 医療移行シート”を使って患者情報を診療所に伝え る. 診療所と病院は “症状継続評価シート”を使つ て継続的に患者の症状につき情報交換し治療を行 う。在宅緩和医療に関しては導入に先立ちがん性疼 痛，せん妄など毎回テーマを定めて繰り返し講習会 を行い，診療所の医師以上に薬局薬剤師，看護師， ケアマネージャーの多くの参加をみた.

4. 地域連携パスのメリット

地域連携パスは患者，かかりつけ医，病院医師に
それぞれ以下の点でメリットがある.

患者：かかりつけ医と病院の follow up を継続し て受けられ，検査の重複や欠落が避けられる.

かかりつけ医：いつどんな診療，検査を行えばよ いか一目瞭然であり，いつ病院を受診するのかがわ かり易い.

病院医師：定期的検査をかかりつけ医にお願いす ることで見落としをなくし，外来診療の質を向上し 得る。さらにかかりつけ医と密度の濃い連携ができ る

5. 地域医療, とりわけがん医療において薬剤師 に期待すること

がん術後補助化学療法における薬剂師の役割とし ては患者への服薬指導, 患者からの有害事象の聴取 と重症度判定, 抗がん剂の休薬, 減量に関する医師 への助言が挙げられる (Fig. 5).

また在宅緩和医療における薬剤師の役割としては

【減量時の投与量 】

薬剤師のチェック

\begin{tabular}{|r|c|c|}
\hline \multicolumn{1}{|c|}{ 減量 } & 初回基準量 & 増量 \\
\hline 休薬 & $40 \mathrm{mg} /$ 回 & $50 \mathrm{mg} /$ 回 \\
\hline 休薬 $\leftarrow 40 \mathrm{mg} /$ 回 & $50 \mathrm{mg} /$ 回 & $60 \mathrm{mg} /$ 回 \\
\hline 休薬 $\leftarrow 40 \mathrm{mg} /$ 回 $\leftarrow 50 \mathrm{mg} /$ 回 & $60 \mathrm{mg} /$ 回 & $75 \mathrm{mg} /$ 回 \\
\hline
\end{tabular}

TS-1 休菜·墄量・再開O目安

\begin{tabular}{|c|c|c|c|}
\hline \multicolumn{4}{|c|}{ 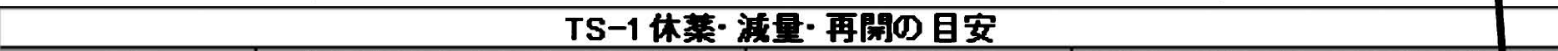 } \\
\hline 且目 & 休蕖を考厙する值・症状など & 再開の目安 & 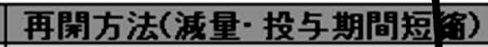 \\
\hline 白血球減少 & $\geqq$ Grade3 $\left(2,000 / \mathrm{mm}^{3}\right.$ 未満 $)$ & $3,000 / \mathrm{mm}^{3} \mathrm{~L}$ 上 & \multirow{3}{*}{ 再開方法の目安に準じる } \\
\hline 好中球減少 & $\geqq$ Grade3 $\left(1,000 / \mathrm{mm}^{3}\right.$ 未満 $)$ & $1,500 / \mathrm{mm}^{3} \mathrm{~L}$ 上 & \\
\hline 血小板減少 & $\geqq \operatorname{Grade} 2\left(7.5\right.$ 万 $/ \mathrm{mm}^{3}$ 未満 $)$ & 10 万 $/ \mathrm{mm}^{3} \mathrm{k}$ 上 & \\
\hline 総ビリルビン & $\geqq$ Grade2 (ULNX2 $\mathrm{mg} / \mathrm{dll}$ 上) & ULNX $2 \mathrm{mg} / \mathrm{dL}$ 未満 & \multirow{2}{*}{ 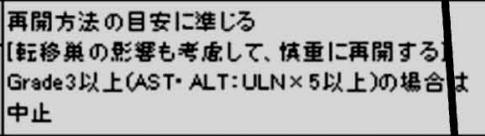 } \\
\hline $\begin{array}{l}\text { AST (GOT) } \\
\text { ALT (GPT) }\end{array}$ & $\geqq$ Grade2（ULNX2IU/Ll:上） & ULNX2IU/L未満 & \\
\hline \multirow{2}{*}{ クレアチニン } & $\geqq$ Grade2 (ULNX1.5mg/dLl以上) & 基本的に再投与しない & 基本的に再投与は行わない \\
\hline & 10 & & 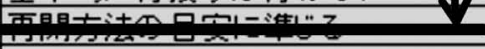 \\
\hline 下痢 & $\geqq$ Grade2 & 症状回復 & \multirow{2}{*}{ 再開方法の 目安に準じる } \\
\hline 口内炎 & $\geqq$ Grade2 & 症状回復 & \\
\hline 嘔吐 & $\geqq$ Grade2 & 症状回復 & \multirow{2}{*}{ 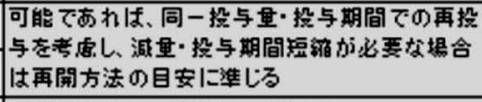 } \\
\hline 亜心、食欲不振 & $\geqq$ Grade2 & 症状回復 & \\
\hline その他 & 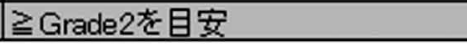 & 症状回復 & 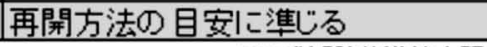 \\
\hline
\end{tabular}

再閉方法の目安

(1)投与開始2週以内に発現の場合: 1 段階の減量を優先して 再開を険討する。

2週以上の投与で悪化が予想される場合は、併せて投与期間の短縮も考虑。

(22週経過後の発現の場合: コース内投与期間の短絆(2週投与1〜2䢙休薬など)を

優先して再開を挨討する。※初回量が80mg/dayの場合、投与期間短䌐で対応。

注意: 休薬·減量·再開の目安であって、絶対的なものではないため、患者の状態や発現の時期などを

考愿して休薬や再開を決定する。

Fig. 5. The Role of Pharmacists in Adjuvant Chemotherapy in Local Community 
麻薬，鎮痛補助剤処方などに関する医師への助言, 在宅における患者症状の把握, 服薬指導などが挙げ られる。

これらはいずれも薬剤に関する専門的知識はもち ろん, 患者, 及びその家族との高度のコミュニケー ション能力を要求される．がん患者の多くは術後経 過観察，抗がん剂治療，在宅緩和医療などの形で闘 病生活の多くの時間を在宅で過ごす。この在宅での 治療において患者とのきめ濃やかなコミュニケーシ ヨンに重点を置き，医師，看護師，訪問看護師，ケ アマネージャーらとの地域チーム医療の中で専門職 として要の役割を担って頂きたい.

\section{6. 地域連携パスに関する今後の課題}

地域連携パスシステムの評価が必要である.

1）術後経過観察の精度は向上したか? 各医療機関の受診率，術後合併症の管理，がん に関する治療成績などにつき定期的な評価が必要 である。ささらに在宅での患者急変時の病院の対 応，患者満足度に関する評価，公表も必要である.

2）診療所に対する過大な負担軽減のために何が できるかの検討を要する.

薬剤師を始めとする多職種によるチーム医療が どこまで実践できるかが診療所に対する負担を軽 減することになると思われる。

7. おわりに

われわれはがんに関する地域医療の原則を以下の 3 点に集約できると考えている．1.がん患者はがん 発見から根治あるいはがん死に至るまで常に地域に いる．2. 病院が果たす役割は手術，化学療法，緩
和医療の振り分け，あるいはそれらの導入のみであ る. 3. 全経過を通じて地域の診療所こそが全人的 医療の要の役割を果たすべきである。これら 3 点の 共通認識の下, 静岡市内 5 力所のすべての総合病院 と約 100 力所の診療所で構築した地域連携パスを紹 介した。 この地域連携では, 診療所と病院との医師 が患者情報を共有するのと同様に，地域の薬局薬剤 師は病院薬剂師と同じように抗がん剂の効果と有害 事象に関する知識を持ち，十分に患者や他の医療者 とコミュニケーションがとれることが要求される. がん診療における地域医療，地域連携の中で薬剤師 全体への期待は極めて大きい.

\section{REFERENCES}

1) e-Gov: 〈http://law.e-gov.go.jp/announce/ H18HO098.html $\rangle$, cited 15 November, 2010.

2) Ministry of Health, Labour and Welfare 〈http: // www.mhlw.go.jp / topics / 2006/02 / tp0201-2.html $\rangle$, cited 15 November, 2010.

3) Tanimizu M., Kawamura S., Narimoto K., Fujii T., Takaoka S., Naga J., Kikuuchi Y., Miyawaki S., Funada C., Matsuhisa T., Gan to Kagaku Ryoho, 34(Suppl. II), 170-174 (2007)

4) Tanimizu M., Kawamura S., Kikuuchi Y., Funada C., Kogure T., Matsuhisa T., Iyaku Journal, 44 (8), 97-103 (2008).

5) Mutou M., Chiryo, 90, 716-720 (2008).

6) Eguchi K., Kanwairyogaku, 11, 351-355 (2009) . 